\title{
Beş Faktör Kişilik Özelliklerinin Örgütsel Sessizlik Üzerine Etkisi: Öğretmenler Üzerine Bir Araştırma (The Effect of Five Factor Personality Traits on Organizational Silence: A Research on Teachers)
}

\section{Hasan DAĞLAR iD a}

a Çankırı Karatekin Üniversitesi, İktisadi ve İdari Bilimler Fakültesi, Çankırı, Türkiye. h. hdaglar@karatekin.edu.tr

\begin{tabular}{|c|c|}
\hline MAKALE BİLGİSİ & ÖZET \\
\hline $\begin{array}{l}\text { Anahtar Kelimeler: } \\
\text { Örgütsel Sessizlik }\end{array}$ & $\begin{array}{l}\text { Amaç - Bu araştırmanın amacı, öğretmenlerin beş faktör kişilik özellikleriyle, işyerinde sergiledikleri } \\
\text { örgütsel sessizlik davranışları arasındaki ilişkilerin ve etkilerin incelenmesidir. }\end{array}$ \\
\hline $\begin{array}{l}\text { Gönderilme Tarihi } 20 \\
\text { Haziran } 2020\end{array}$ & $\begin{array}{l}\text { Yöntem - Araştırmanın bağımlı değişkenini örgütsel sessizlik, bağımsız değişkenini ise beş faktör kişilik } \\
\text { özellikleri oluşturmaktadır. Bunun için örgütsel sessizlik ölçeği ve beş faktör kişilik özellikleri ölçeği ile } \\
\text { birlikte demografik sorulardan oluşan bir anket formu hazırlanmıştır. Çankırı ilinde çeşitli branşlarda } \\
\text { görev yapan toplam } 401 \text { öğretmen araştırmaya katılmıştır. Anketlerle elde edilen veriler SPSS paket } \\
\text { programının 22. versiyonu kullanılarak kişilikle örgütsel sessizlik arasındaki ilişkilerin istatistiksel } \\
\text { analizi yapılmıştır. }\end{array}$ \\
\hline $\begin{array}{l}\text { Revizyon Tarihi } 26 \\
\text { Temmuz } 2020 \\
\text { Kabul Tarihi } 10 \text { Eylül } 2020\end{array}$ & $\begin{array}{l}\text { Bulgular - Öğretmenlerin örgütsel sessizliğinin cinsiyetlerine göre anlamlı bir fark oluşturduğu, kadın } \\
\text { öğretmenlerin okuldaki sorunlarla ilgili bilinçli olarak sessiz kalmayı tercih ettikleri bulunmuştur. } \\
\text { Öğretmenlerin mesleki tecrübelerine göre örgütsel sessizlik davranışlarının anlamlı bir fark gösterdiği, } \\
\text { tecrübeli öğretmenlerin daha az sessiz kaldıkları görülmektedir. Bağımlı değişken olan örgütsel } \\
\text { sessizlikle, bağımsız değişkenler olan beş faktör kişilik özelliklerinin alt boyutları arasında negatif olarak } \\
\text { düşük derecede bir ilişki bulunmuştur. Dışa dönüklük ve duygusal dengelilik değişkenlerinin örgütsel } \\
\text { sessizlik üzerinde istatistiki olarak anlamlı bir etkisi olduğu bulunmuştur. }\end{array}$ \\
\hline Makale Kategorisi: & $\begin{array}{l}\text { Tartışma - Kadın öğretmenlerin ve mesleki tecrübesi az olan öğretmenlerin diğerlerine göre daha çok } \\
\text { sessiz oldukları, bu gruptaki öğretmenlerin fikirlerini dile getirmeleri için yöneticilerin daha hassas } \\
\text { davranması ve cesaretlendirmeleri gerekmektedir. Beş faktör kişilik özellikleriyle örgütsel sessizlik } \\
\text { davranışları arasında ilişki olduğundan yöneticilerin öğretmenlerin görüşlerini almalarında ve } \\
\text { yönetime katılmalarını sağlamalarında kişilik özelliklerine dikkat etmeleri ve çalışanların fikir, görüş ve } \\
\text { düşüncelerini rahatça ifade edebilecekleri, açıç̧a konuşmalarını teşvik edecek ortamları oluşturmaları } \\
\text { faydalı olacaktır. }\end{array}$ \\
\hline
\end{tabular}

\begin{tabular}{l}
\hline ARTICLE INFO \\
\hline Keywords: \\
Organizational Silence \\
Personality \\
Participatory Management
\end{tabular}

Received 20 June 2020

Revised 26 July 2020

Accepted 10 September 2020

Article Classification: Research Article

\section{ABSTRACT}

Purpose - The purpose of this research is to examine the relationships and effects between teachers' fivefactor personality traits and organizational silence behaviors displayed in the workplace.

Design/methodology/approach - The dependent variable of the research is organizational silence and the independent variable is the five-factor personality traits. For this, organizational silence scale and a questionnaire form consisting of five-factor personality traits scale and demographic questions were prepared. Total 401 teachers working in various branches in Çankırı, participated in the research. The data obtained through the questionnaires were statistically analyzed the relationships between personality and organizational silence using the 22nd version of the SPSS package program.

Findings - It was found that the organizational silence of the teachers made a significant difference according to their gender and female teachers preferred to remain quiet consciously about the problems at school. According to teachers professional experience, it is seen that organizational silence behaviors show a significant difference and experienced teachers remain less silent. A negative low correlation was found between organizational silence which is the dependent variable and the sub-dimensions of fivefactor personality traits which are independent variables. Extraversion and emotional stability variables were found to have a statistically effect on organizational silence significantly.

Discussion - Teachers who have little professional experience and female teachers are more quiet than others, so in order for the teachers in this group to express their opinions, administrators should be more sensitive and encouraging. Due to the relationship between five factors personality traits and organizational silence behaviors, managers need to pay attention to personality traits while getting teachers' opinions and participating in management, so it would be beneficial for the employees to provide an environment where they can easily express their opinions and thoughts.

\section{Önerilen Atıf/ Suggested Citation}

Dağlar, H. (2020). Beş Faktör Kişilik Özelliklerinin Örgütsel Sessizlik Üzerine Etkisi: Öğretmenler Üzerine Bir Araştırma, İşletme Araştırmaları Dergisi, 12 (3), 2487-2500. 


\section{Giriş}

Bir örgütte çalışanların örgütteki sorunlar ve değişimle ilgili fikir ve düşüncelerini seslendirmeleri katılımcı ve demokratik yönetim, iyi bir iletişim ve örgütün gelişimi açısından büyük önem taşımaktadır. Çalışanların sorunları bildikleri halde çeşitli sebeplerle, bilinçli ve kasıtlı olarak görüşlerini dile getirmedikleri ve topluca sessiz kalabildikleri görülmektedir. Çalışanların fikir, görüş ve önerilerinden yararlanabilmek için örgütsel sessizlik bir sorun olarak değerlendirilmektedir.

Örgütlerde sessizlik ve ses karmaşık ve çok boyutlu konulardır. Örgütsel sessizliği anlamak ve dile getirmek, örgütte konuşmaların analizine göre oldukça zordur. Çünkü çalışanların ne zaman konuşmadıkları, hangi sorunları dile getirmede sessiz kaldıkları ve kimin karşısında konuşmadıklarını anlamak oldukça zordur. Çalışanlar bilgi sahibi olmadığı konularda sessiz kalabilirler ancak örgütsel sessizlik çalışanların örgütteki sorunlar ve konular hakkında belirli bir bilgiye sahip olmalarına rağmen çeşitli sebeplerle bilinçli olarak bunları üstlerine aktarmaması veya seslendirmemesini ifade eder.

Türk Dil Kurumu sözlüğünde ses, kulağın duyabildiği titreşim, seda, duygu ve düşüncedir. Sessizliğin anlamı, ortalıkta gürültü olmama durumu ve sükût olarak tanımlanmaktadır. Sessizlik, duygu ve düşüncelerin ifade edilmemesidir. Sessizleşmek ise, sessiz duruma gelmek, sessiz olmak şeklinde açıklanmaktadır (TDK, 2020).

Örgütsel sessizliğin karşıt ifadesi olan açıkça konuşma veya örgütsel seslilik ise, çalışanların örgütteki sorunlar ve alternatif yaklaşımlar hakkındaki düşünce, fikir ve görüşlerini açık bir şekilde ifade etmeleri yani seslendirmeleridir.

Örgütsel sessizlik, örgütlerde değişim ve gelişim, çalışanların katılımı, fikir ve görüşlerinden yararlanılması ve çoğulcu örgütlenmeler için önemli bir engel olarak görülmektedir. Çoğulcu bir örgüt çoklu bakış açıları ile fikirlerin ifade edilmesine izin verir. Çalışanlar kritik konulardaki fikirlerini açıkça ifade edemeyeceklerini hissediyorlarsa o zaman çoğulculuk sağlanamaz. Örgütsel sessizlik, çalışanların güvenini, iş tatminini, moralini, örgütsel bağlılığını, uyumunu olumsuz etkileyebilir (Morrison ve Milliken, 2000:707).

Katılımcı, demokratik, açık iletişime dayalı yönetim uygulamaları arzu edilen ancak gerçekleştirilmesi zor bir konu olarak görülmektedir. Gelişme ve ilerleme için çalışanların fikirlerini çekinmeden rahatlıkla söyleyebilmeleri ve yönetimin ortak aklı kullanabilmesi önemlidir. Çalışanların örgütteki sorunları dile getirememeleri verimliliklerinde ve iş başarılarında düşmeye yol açabilir. Bu yüzden çalışanların örgütsel sessizlik davranışı göstermelerinin kişilik özellikleriyle ilişkisinin olup olmadığı merak edilmiş ve bu durumun araştırılması gereken bir konu olabileceği düşünülmüştür.

Örgütsel sessizlik çalışanın ve örgütün performansını etkileyen olumsuz bir davranış olarak ele alınmakta ve katılımcı bir örgüt meydana getirilmesinin önündeki önemli bir engel olarak görülmektedir. Örgütsel sessizliği meydana getiren şartlar ve konuşmanın mantıksız olduğu ve işe yaramayacağı şeklindeki ortak algiyı oluşturan duygusal sebepler merak konusu olmuş ve araştırılmaya değer görülmüştür.

$\mathrm{Bu}$ araştırmanın amacı, öğretmenlerin beş faktör kişilik özellikleriyle, işyerinde sergiledikleri örgütsel sessizlik davranışları arasındaki ilişkilerin incelenmesi ve beş faktör kişilik özelliklerinin alt boyutlarının örgütsel sessizlik üzerinde etkilerinin olup olmadığının araştırılmasıdır.

\section{1. Örgütsel Sessizlik}

Örgütlerde sorunların veya bazı konuların çalışanlar tarafından bilinmesine rağmen çeşitli sebeplerle hiçbir çalışan tarafından dile getirilmemesine örgütsel sessizlik denilmektedir. Örgütsel sessizlik, çalışanların toplu olarak örgütteki sorunlar hakkındaki fikir, düşünce ve kaygılarını bilinçli olarak esirgemeleri, dile getirmemeleri ve yönetimle paylaşmama tercihleridir (Morrison ve Milliken, 2000:706).

Araştırmalara göre çalışanların sessiz kalma nedenleri; şikayetçi biri olarak görülmek, saygı ve güven kaybına uğramak, ilişkilere zarar vermek, işten atılmak, terfi edememek gibi korkular ile konuşmanın fayda etmeyeceği inancıdır (Çakıcı, 2008:118).

Örgütsel sessizlik tek bir çalışanın örgütte neden sessiz kalmayı tercih ettiğini açıklamak değil, çalışanların örgütsel konu veya sorunlar karşısında toplu olarak neden sessiz kaldıklarını, fikirlerini ve görüşlerini 
açıklamaktan bilinçli olarak neden kaçındıklarını ifade etmektedir. Kişileri sessiz kalmaya zorlayan bireysel faktörlerin dışındaki diğer faktörlerin neler olduğu üzerinde durulmaktadır (Morrison ve Milliken, 2000:707).

Sessizliği anlamak ve yorumlamak konuşmaya göre daha zordur. Çalışanların örgütsel konu ve sorunlarla ilgili neden ve nasıl sessizleştiklerini ortaya çıarmak önemlidir. Türk deyimleri ve atasözlerinde sessiz kalmak ve konuşmamakla ilgi bazı deyimler ve sözler vardır. "Söz gümüşse sükût altındır", "Erken öten horozun başını keserler" ve "Etliye sütlüye karışmayacaksın işini yapacaksın" gibi sözler açıç̧a konuşmanın sıkıntı meydana getireceğini ve sessiz kalmayı ön plana çıkaran ifadelerdir (Çakıcı, 2007:147).

Çalışanların çoğunun örgüt içindeki belirli konular ve sorunlarla ilgili gerçeği bildikleri halde bunu üstlerine söylemeye cesaret edemedikleri, bunun bir çelişki oluşturduğu ve niçin böyle davrandıkları araştırmacılar tarafından ortaya çıkarılmaya çalışılmaktadır. Çalışanlar topluca örgütsel sorunlara ilişkin görüşlerini ve endişelerini bilinçli olarak saklayabilmekte ve sessiz kalabilmektedir. Çalışanların sorunları dile getirmeme sebeplerinin başında konuştuklarında olumsuz tepkiyle karşılaşacakları ve konuşmalarının bir işe yarayacağına inanmamaları gelmektedir.

Örgütsel sessizlik ortamının dayandığı ortak inançlar şunlardır (Morrison ve Milliken, 2000:714):

1. Örgütteki sorunlardan bahsetmek çaba sarf etmeye değmez. Çalışanlar arasında iş yerindeki problemler veya konular hakkında konuşmanın boşuna veya tehlikeli olduğuna yönelik bir algı varsa örgütsel sessizlik oluşacaktır.

2. Çalışanların görüşlerini ve endişelerini dile getirmeleri tehlikelidir. Çalışanlar sorun çıkarıcı, dedikoducu veya şikayetçi birisi olarak adlandırılmaktan korktukları için sessiz kalabilmektedirler.

3.Örgütteki sorunlar ve önemli konular hakkında "yönetim en iyisini bilir" inancı ve üst düzey yöneticilerin özellikle astlarından olumsuz geri bildirim alma korkusu da örgütsel sessizliğe neden olabilmektedir.

Örgütsel sessizliği oluşturan ve devam ettiren inançların ve davranış şekillerinin değiştirilmesi oldukça zordur. Sessizlik iklimi olan organizasyondan sesi, çok sesliliği ve konuşmayı teşvik eden organizasyona geçmek sistemde köklü bir değişiklik gerektirebilir. Çoğulculuktan ve çalışanların fikirlerinden yararlanmak için çalışanların konuşmalarının teşvik edilmesi gerekir. Örgütsel değişim ve gelişimin önündeki bir engelin de örgütsel sessizlik olduğu görülmektedir.

\subsection{1. Örgütsel Sessizlik Çeşitleri}

Çalışanların genellikle iş ve organizasyonun gelişimi ile ilgili yapıcı fikirleri, bilgileri ve görüşleri olmasına rağmen, bu görüş ve düşüncelerini kasıtlı olarak ifade etmeme yani esirgeme davranışı örgütsel sessizliği oluşturur. Örgütteki önemli konular ve sorunlar hakkında konuşma da örgütsel sesliliği oluşturur. Üç çeşit sessizlik vardır:

Kabullenici sessizlik: Çalışanların herhangi bir konu ya da sorunla ilgili konuşmanın anlamsız olduğu, konuşarak bir şeyi değiştiremeyecekleri inancına sahip olmalarından dolayı sessiz kalmalarıdır. İşle ilgili fikirlerin, bilgilerin ve görüşlerin saklandığı, çalışanın mevcut durumu ve örgütsel şartları olduğu gibi kabulü şeklinde yorumlanan bir eylemsizlik şeklidir (Van Dyne vd, 2003:1366).

Kabullenici sessizlik çalışanların iş hayatında "Konuşsam da yararı yok" düşüncesine kapılıp "Boşver böyle gelmiş böyle gider", "boşuna çeneni yorma, hiçbir şeyi değiştiremezsin" gibi sözlerle kabul edilen sessizliktir (Çakıc1, 2010:32). Kabullenme, istemeyerek kabul etmek zorunda kalma olarak açıklanmaktadır.

Savunmacı Sessizlik: Konuşmanın sonuçlarının birileri tarafından hoş karşılanmayacağı korkusuna dayanarak, çalışanın başkalarına yönelik olarak kendini koruma amaçlı sessiz kalması ve ilgili fikirlerinin daha aktif olarak tutulmasıdır. Çalışanlar kötü haber vermekten kaçınmak, fikirlerinin ifadesinin riskli olduğu korkusu, kendini korumak ve sorunlardan sorumlu tutulmamak ve mevcut ilişkileri bozmamak amacıyla sessiz kalabilirler. Sesini çıkartmak ise, çalışanların önlem alıcı bir şekilde değişim için önerilerde bulunmasidır (Van Dyne vd, 2003:1367).

Savunma, saldırıya karşı koyma olarak açıklanmaktadır. Kabullenme, çözümlenemeyen olumsuz bir duruma ilişkin bireyin bunu içselleştirdiği tepki olup pasif niteliktedir. Savunma ise kabullenmeye göre daha aktif bir tepkidir (Şimşek ve Aktaş, 2014:132). 
İlişkisel sessizlik: Kişilerin değer verdikleri ilişkileri korumak amacıyla sessiz kalmalarıdır. İş ile ilgili gizli ve özel bilgilerin korunması, iş birliği güdüsüne bağlı olarak bilinçli bir şekilde örgüt yararına sessiz kalmadır. Çalışanların örgütteki şartların iyileştirilmesine yönelik gerçek fikirlerini gizlemeleri ve paylaşmamalarıdır.

Çalışanlar iş yerinde uğradığı kötü muamelelerden ve konuşmanın sonuçlarından korktuklarından dolayı sessiz kalabilmektedir. Sessizlik yapılan faaliyeti onaylamama anlamına gelen bir iletişim türüdür. Sessizlik, yazılı bir mektup, sözlü ifade, beden dili veya elektronik posta ile gönderilen bir mesaj ile kırılabilir. Örgütsel sessizliği önlemek için açık kapı politikaları, şikâyet mekanizmaları ve kamu denetimleri gereklidir (Pinder ve Harlos, 2001:360).

\subsection{Kişilik}

Kişilik bireyin bütün özelliklerini yansıtan ve onu diğer kişilerden ayırarak kendine özgü kılan özellikler bütünüdür. Kişilik, bireyin zihinsel, bedensel ve psikolojik farklılıklarının kendi davranış biçimlerine ve yaşama tarzına yansımasıdır. Bireyi diğer insanlardan ayıran ve kendisi yapan kalıcı özellikler bütünüdür (Tutar, 2016:43).

Bireyler fiziksel görünümleriyle olduğu kadar tutum ve davranışları itibariyle de birbirlerinden farklılık gösterir. Olaylar, insanların hareketleri, duyguları ve fikirleri bakımından birbirlerinden farklı olduklarını göstermektedir. İnsanın başkaları açısından kişiliği, onun toplum içinde belirli özelliklere ve rollere sahip olmasıdır. Kişilik doğuştan var olan ve sonradan edinilen eğilimlerin bütününden meydana gelmiştir (Eren, 2008:83).

\subsubsection{Beş Faktör Kişilik Özellikleri ve Alt Boyutları}

Kişiliği belirlemede nitel ve nicel olmak üzere iki farklı araştırma yönteminden yararlanılmakta olup, nicel ölçütler ölçülebilir özellikler taşıdığından daha yaygın olarak kullanılabilmektedir. Beş faktör kişilik özellikleri, bireylerin kişilik yapılarını tanımlamak için kullanılan sıfatların faktör analizine tabi tutulması sonucu geliştirilmiştir. Beş faktör kişilik ölçeği, kişilik yapılarını bütünleştirmesi, kişilik özellikleriyle davranışlar arasındaki korelasyonun incelenebilmesine ve kişiliği beş alt faktörle sınırlandırması nedeniyle tercih edilmektedir (Tutar, 2016:63).

Beş faktör kişilik özellikleri; dışa dönüklük, uyumluluk, sorumluluk, duygusal dengelilik ve deneyime açıklık olmak üzere kişilik özelliklerini beş temel alt boyutta toplamaktadır.

Dışa dönüklük: Sosyal, girişken, konuşkan, yaşam dolu cana yakın ve heyecanlı olma gibi özellikler dışa dönüklük alt boyutunda toplanmaktadır. Dışa dönük kişiler yeni sosyal ilişkiler kurmaya açık, pozitif, enerjik, neşeli ve diğerlerine karşı ilgili olan kimselerdir. Dışa dönüklük düzeyi düşük olan içe dönük kimseler ise diğer insanlara mesafeli, kapalı, yalnız kalmayı seven kişilerdir (Gosling vd. 2003:523).

Uyumluluk: Yumuşak başlılık, hassas düşünce, doğruluk, dürüstlük, güven, fedakârlık, alçakgönüllülük gibi özellikler uyumluluk alt boyutunda toplanmaktadır. Uyumlu kişiler, başkalarına karşı yumuşak başlı, fedakâr, alçakgönüllü ve iş birliğine isteklidirler. Uyumluluk düzeyi düşük olanlar, düşmanca, güvenilmez, inatçı, geçimsiz, kaba ve şüpheci kişilik özellikleri göstermektedir (Costa vd. 1991:888).

Sorumluluk: Başarı çabası, azimli, görev temelli davranma, çalışmaya bağlılık, yeterlilik, hırslı, titiz, düzenli, öz disiplin ve tedbirli olma gibi özellikler sorumluluk alt boyutunda toplanmaktadır. Sorumluluk düzeyi yüksek kişiler disiplinli, dikkatli ve başarma duygusu yüksektir. Sorumluluk düzeyi düşük olan kişiler dikkatsiz, tembel ve dağınık olmaktadır (Costa vd. 1991:889).

Duygusal dengelilik: Sakin, kendine güvenen, pozitif duygulu, kaygısız yani nevrotik olmayan özellikler duygusal dengelilik alt boyutunda toplanmaktadır. Duygusal dengesi yüksek olan kişiler sakin ve kendine güvenen kişilik özellikleri gösterir. Duygusal denge düzeyi düşük olanlar ise, endişeli, gergin, sinirli, içine kapanık, düşüncesiz, özgüveni düşük özellikler göstermektedir (Gosling vd. 2003:524).

Deneyime açıklık: Değişikliği seven, yeniliklere açık, hayal gücü yüksek, meraklı, cesur, bağımsız, liberal ve analitik özellikler yeniliğe açıklık alt boyutunda toplanmıştır. Deneyime açık olan kimseler, hayal kuran, meraklı, maceracı ve yeniliklere açık kişilerdir. Deneyime açık olmayanlar ise, değişime direnen, yeniliklere kapalı, sabit fikirli, tutucu ve geleneksel özellikler göstermektedir (Gosling vd. 2003:524). 
Beş faktör kişilik özelliklerinin belirlenmesinde kullanılan ölçeklerin uzun olması ve doldurulmalarının çok zaman almasından dolayı daha kısa ölçeklerin geliştirilmesi çalışmaları yapılmıştır. Beş faktör kişilik özelliklerini çok sayıda dolaylı sorular sorarak belirlemek yerine daha az sayıda ve doğrudan sorular sorarak belirleyen geçerliliği ve güvenilirliği test edilmiş ölçekler geliştirilmiştir (Gosling vd. 2003:524).

Kişiliği en kapsamlı şekilde tanımlayan, beş alt boyuttan oluşan ve her alt boyut için iki maddenin bulunduğu on maddelik beş faktör kişilik ölçeğini Türk kültürüne uyarlama çalışmaları yapılmıştır (Horzum vd. 2017:404). Beş faktör kişilik özellikleri ölçeğinin Türk kültüründe geçerli ve güvenilir bir ölçme aracı olduğu ve kişiliği ölçmek için kullanılabileceği ortaya konulmuştur (Atak, 2013:317).

\subsection{Literatür İncelemesi}

Yapılan literatür taramasında, bireylerde gözlemlenen birçok kişilik özelliği olmasına rağmen araştırmalar sonucu bulunan beş faktör kişilik modelinin oldukça yararlı bir sınıflama olduğu görülmüştür. Beş faktör kişilik modeli belli aralıklarla yapılan faktör analizleri sonucunda zaman, bağlam ve kültür gibi özellikler gözetilerek bulunmuştur. Beş faktör yapısı, insanı tanımlayan kişilik özelliklerini belirlemede önemli bir faktör olmasının yanında diğer taraftan da dikkate değer bir sınıflama vermektedir (Tatlılığlu, 2013:142).

Kişilikle ilgili birçok görüş ortaya atılmış olmasına rağmen, kişiliği belirlemek için beş faktör kişilik özelliklerinin daha yaygın olarak kullanıldığı görülmektedir. Beş faktör kişilik modeli, bireysel kişiliği belirleyen beş önemli faktör ile bunlarda yaşanan değişikliklerin neyi, nasıl etkilediklerinin açıklanmasıdır (Tozkoparan, 2013:197).

Kişilik özelliklerinin örgütsel sessizlik üzerindeki etkisine yönelik yapılan bir araştırmada; dışa dönüklük özelliği yüksek olan çalışanların örgütte sessiz kalma eğilimlerinin daha düşük olduğu, sorumluluk sahibi ve deneyime açık kişilerin fikirlerini paylaşma eğiliminde oldukları, gerektiğinde eleştirilerini rahatlıkla ortaya koyabildikleri sonucuna ulaşılmıştır. Örgüt içerisinde çalışanların sessiz kalma eğiliminde olma nedenleri arasında kişilik özelliklerinin önemli bir oranda etkisinin olduğu ifade edilmiştir (Tokmak, 2018:2230).

Beş faktör kişilik özelliklerinin iş yaşamında yalnızlık üzerine etkisinin incelenmesine yönelik olarak yapılan bir araştırmada; çalışmanın bağımsız değişkeninin beş faktör kişilik özellikleri olan, dışadönüklük, duygusal denge, uyumluluk sorumluluk ve açıklık olmak üzere beş boyuttan oluştuğu belirtilmiştir. Sosyal olma, konuşkanlık, insanlara dönük olma gibi kişilik özelliklerine sahip olanların dışa dönüklük boyutunun yüksek olduğu; azimli, hırslı, başarma yönelimli, sistemli ve titiz çalışanların sorumluluk düzeylerinin yüksek olduğu ifade edilmiştir. Ayrıca beş faktör kişilik özelliklerinin iş yaşamında yalnızlık üzerinde etkisinin olduğu ortaya konulmuştur (Parlak ve Koçoğlu Sazkaya, 2018:162).

Beş faktör kişilik modeli ve örgütsel muhalefet arasındaki ilişki üzerine yapılan bir araştırmada; dışa dönük kişilik özelliklerine sahip olanların ne düşündüklerini açıcça söyleyen, hakkını savunan, önderlik eden ve girişken kişiler olduklarından açı muhalefet stratejisini daha çok kullandıkları ve örgüt içerisindeki işlerin yapılış şekli ve verimlilikle ilgili önerileri ve eleştirileri üst yönetime rahatlıkla söyleyebildikleri belirtilmiştir. Beş faktör kişilik modelinde yer alan duygusal dengenin hem dişsal muhalefeti hem de gizli muhalefeti negatif yönde açıkladığı belirtilmiştir (Ötken ve Cenkci, 2013:48).

Beş faktör kişilik özelliklerinin kişilerarası çatışma çözme yaklaşımlarıyla ilişkisi üzerine yapılan araştırmada; kişilerin çatışma çözme yaklaşımları benimsemesinde kişilik özelliklerinin önemli rol oynadığı, kişilik yapısı itibariyle gelişime açılık düzeyleri yüksek, özdisiplini yüksek, dışa dönük ve uyumluluğu yüksek kişilerin, çatışma çözmede yüzleşme yaklaşımını benimsedikleri ifade edilmiştir (Basım, Çetin ve Tabak, 2009:31).

Bireylerin kişilik özelliklerinin işveren çekiciliği algısına etkisi isimli araştırmada; beş faktör kişilik ölçeği boyutları olan sorumluluk, uyumluluk, dışa dönüklük ve duygusal dengesizlik boyutları ile işveren çekiciliği boyutları olan sosyal değer, ekonomik değer, gelişim değeri, fayda değeri ve başvuru değeri boyutları arasında anlamlı ilişkiler tespit edilmiştir (Ardıç ve Gündoğmuş, 2016:11).

Bireylerin kişilik özellikleriyle örgütsel sessizlik davranışları, sessizliğe yönelik nedenleri ve stratejilerinin güçlü bir biçimde etkileştiği tespit edilmiştir. Dışa dönük ve yeniliklere açık olanlar, daha az kabullenici sessizlik davranışı göstermektedirler. Dışa dönükler daha az savunmacı sessizlik davranışı göstermektedir. Sorumlu ve deneyime açık olanlar, daha çok ilişkisel sessizlik davranışı göstermektedir (Şimşek ve Aktaş, 2014:133). 
Üniversitelerde örgütsel sessizlikle ilgili yapılan bir araştırmada; üniversitedeki sorunlarla ilgili üniversite personelinin yüzde yetmişi sessiz kalmayı tercih ederken, yüzde otuzu açıkça konuşma yolunu seçmektedir. Sessiz kalınan konular; etik konular ve sorumluluklar, yönetim sorunu, çalışanların performansı, kurumu iyileştirme konuları ve çalışma olanakları olarak belirlenmiştir. Çalışanların sessiz kalmayı tercih etme nedenlerinin başında yönetsel ve örgütsel nedenler gelmektedir (Çakıc1, 2008:130).

Örgütsel sessizliğin çalışanların performansı ile ilişkisi konusunda yapılan araştırmada; kabul edilen sessizlik, savunma amaçlı sessizlik ve örgüt yararına seslilik arttıkça çalışanların performansında düşüş yaşanabildiği, çalışanların örgütsel duruma razı oldukları için alternatif yollar bulamadıkları ve sorunların çözümünde yetersiz kaldıkları tespit edilmiştir (Tayfun ve Çatır, 2013:128).

Örgütsel sessizlikle ilgili öğretmenler üzerinde yapılan bir araştırmada; öğretmenlerin sessiz kalma sebeplerinin başında, konuştuklarında olumsuz imaj bırakma, ceza alma, dışlanma, kötü muamele görme, sorumluluğun kendi üzerinde kalması, çoğunluktan ayrı düşmeme gibi olumsuz sonuçlarla karşılaşma korkusunun geldiği tespit edilmiştir. Ayrıca bir şeyleri değiştiremeyecekleri düşüncesi de kabullenici sessizlik olarak ortaya çıkmaktadır. Örgütsel sessizliğin çalışanların fikir, görüş ve düşüncelerini rahatlıkla ve korku duymadan dile getirebilecekleri ortamlar oluşturularak önlenebileceği vurgulanmıştır (Ayduğ vd. 2017:1135).

Çalışanların sessizlik davranışları, kişisel özelliklerine, örgüt yönetimine, alt yönetsel düzeylere ve örgütün genel olarak iletişim yapısına göre değişiklik gösterebilmektedir. Bu davranışların altında yatan eğilimin ilgisizlik, uysallık, boyun eğme, kendini koruma, ilişkileri koruma gibi hangi yönde olduğunu bilmek gerekir (Alparslan ve Kayalar, 2012:145).

Örgütsel sessizlikle ilgili üniversitelerde yapılan bir araştırmada, sessizlik davranışının olumsuz etkilerinin tüm örgütlerde olduğu gibi üniversitelerde de görüldüğü tespit edilmiştir. Özellikle üniversitelerde yeni bilgilerin edinilmesi için akademik personelin bilgi, fikir ve görüşlerini açıça ifade edebilmelerinin önemi belirtilmiştir. Bunun için iletişim kanallarının açık olması, astların üstleriyle rahatça iletişim kurabilmeleri, güven ve bilgi paylaşımına dayalı katılımcı, şeffaf ve çoğulcu örgüt yapısının ve yönetim anlayışının güçlendirilmesinin gerektiği vurgulanmıştır (Çavuşoğlu ve Köse, 2016:140).

Çalışanların örgütleriyle ilgili yapııı fikir, öneri ve düşüncelerini bilinçli olarak paylaşmamayı tercih etmeleri anlamına gelen çalışan sessizliği, örgütlerin değişimini ve gelişimini olumsuz etkileme potansiyeline sahiptir. Bu nedenle, çalışanların endişelerini, fikirlerini ve farklı görüşlerini ifade etmelerini sağlamak yöneticiler için oldukça önemlidir (Erenler, 2010:6).

\subsection{Araştırma Hipotezleri}

Araştırmaya katılan öğretmenlerin mesleki tecrübe ve cinsiyetleri ile örgütsel sessizlik davranışları arasında anlamlı bir farklılık olup olmadığına ve beş faktör kişilik özelliklerinin örgütsel sessizliğe etkilerine yönelik hipotezler oluşturulmuştur.

H1: “Öğretmenlerin örgütsel sessizliği cinsiyetlerine göre anlamlı bir farklılık gösterir.

H2: “Öğretmenlerin örgütsel sessizliği meslekteki tecrübelerine göre anlamlı bir farklılık gösterir.

H3. “Öğretmenlerin beş faktör kişilik özelliklerinin örgütsel sessizlik davranışı üzerinde anlamlı bir etkisi vardır.

H31. Öğretmenlerin beş faktör kişilik özelliklerinden dışa dönüklük alt boyutunun örgütsel sessizlik üzerinde anlamlı bir etkisi vardır.

H32. Öğretmenlerin beş faktör kişilik özelliklerinden uyumluluk alt boyutunun örgütsel sessizlik üzerinde anlamlı bir etkisi vardır.

H33. Öğretmenlerin beş faktör kişilik özelliklerinden sorumluluk alt boyutunun örgütsel sessizlik üzerinde anlamlı bir etkisi vardır.

H34. Öğretmenlerin beş faktör kişilik özelliklerinden duygusal dengelilik alt boyutunun örgütsel sessizlik üzerinde anlamlı bir etkisi vardır.

H35. Öğretmenlerin beş faktör kişilik özelliklerinden deneyime açıklık alt boyutunun örgütsel sessizlik üzerinde anlamlı bir etkisi vardır. 


\section{Yöntem}

\subsection{Araştırma Modeli}

Araştırma beş faktör kişilik özelliklerinin örgütsel sessizlik üzerindeki etkisini istatistiksel teknikler kullanarak tespit etmeyi amaçlayan betimsel bir araştırmadır. Öğretmenlerin çeşitli demografik değişkenlere göre işyerinde sessizlik davranışı gösterip göstermedikleri ve kişilik özelliklerinin buna etkisi araştırılmıştır. Araştırmanın bağımlı değişkenini örgütsel sessizlik, bağımsız değişkenini ise beş faktör kişilik özellikleri oluşturmaktadır. Araştırma bağımsız değişkenlerin bağımlı değişken üzerine etkilerini inceleyen nicel bir araştırmadır. Bunun için örgütsel sessizlik ölçeği ve beş faktör kişilik özellikleri ölçeği ile birlikte demografik sorulardan oluşan bir anket formu hazırlanmış ve araştırmaya katılan öğretmenler tarafından doldurulması sağlanmıştır. Anketlerle elde edilen veriler SPSS paket programının 22. versiyonu kullanılarak bilgisayara aktarılmış ve kişilikle örgütsel sessizlik arasındaki ilişkiler analiz edilmiştir.

\subsection{Araştırmanın Evreni ve Örneklemi}

Araştırmanın evrenini Çankırı ilinde bulunan MEB' e bağlı anaokulu, ilkokul, ortaokul ve liselerde çeşitli branşlarda 2019-2020 öğretim yılında görev yapan 1833 öğretmen oluşturmaktadır. Örnekleme yöntemlerinden kolayda örnekleme yöntemi kullanılmış ve zengin bir örnekleme ulaşabilmek ve genellenebilirliği artırmak için okul türlerinin tamamında çalışan öğretmenlere anket gönderilmiştir. Gönüllü olarak araştırmaya toplam 401 öğretmen katılmıştır. Örneklem büyüklüğünün belirlenmesinde kullanılan hazır tablolara göre 1900 olan bir ana kütle için 320 örneklem yeterli olduğundan, burada 1833 olan ana kütle için 401 olan örneklem büyüklüğünün araştırma evrenini temsil ettiği görülmektedir (Karagöz, 2017:61).

Araştırmada kişilerden veri toplandığı için Çakırı Karatekin Üniversitesi Etik Kurulu'nun 12.05.2020 tarih ve 208 nolu kararıyla etik kurul izni alınmıştır. Öğretmenlerle anket yapıldığı için ayrıca Çankırı Milli Eğitim Müdürlügünden de izin alınmıştır.

\subsection{Veri Toplama Araçları}

Araştırmada veri toplama aracı olarak anket tekniğinden yararlanılmış olup, anket formu üç bölümden oluşmuştur.

Demografik Bilgi Formu: Cinsiyet, yaş, medeni durum, öğrenim durumu, çocuk sahibi olma durumu, kaç yıldır bu mesleği yaptığı ve şu anki kurumunda kaç yıldır çalıştı̆̆ına ilişkin sorulardan oluşmuştur.

Örgütsel Sessizlik Ölçeğgi: İ. Durak (2014) tarafından geliştirilmiş geçerlik ve güvenilirliği test edilmiş örgütsel sessizlik ölçeğindeki ifadelerden yararlanılarak 19 ifadeden oluşan ölçek oluşturulmuştur. Ölçeğin Cronbach's Alpha güvenilirlik katsayısı 0.875 olarak hesaplanmış ve ölçeğin oldukça yüksek güvenilirliğe sahip olduğu tespit edilmiştir.

Beş Faktör Kişilik Ölçeği: Gosling ve arkadaşları tarafından kişilik ölçeği olarak geliştirilen ve kişiliğin beş faktör modelini esas alan on maddelik ölçek kullanılmıştır (Gosling vd. 2003:525). Ölçek beş önemli kişilik özelliği olan dışadönüklük, uyumluluk, sorumluluk, duygusal dengelilik ve deneyime açılık olan kişiliğin alt boyutlarını ölçmektedir. On maddeyle beş faktör kişilik özelliğini ölçen bu ölçeğin Türk kültüründe geçerli ve güvenilir bir ölçme aracı olduğu ve kişiliği ölçmek için kullanılabileceği yapılan bilimsel çalışmalarla ortaya konulmuştur (Atak, 2013:317). Beş faktör kişilik ölçeğinin tamamının Cronbach's Alpha güvenilirlik katsayısı 0,725 , dişa dönüklük alt boyutu için 0.765 , uyumluluk alt boyutu için 0.703 , sorumluluk alt boyutu için 0.719 , duygusal dengelilik alt boyutu için 0.707 , deneyime açılık alt boyutu için 0.704 olarak hesaplanmış ve ölçeğin güvenilir olduğu tespit edilmiştir.

Ölçeklerde yer alan ifadelerin cevapları için beş aralıklı Likert tipi ölçek kullanılmıştır. 1-Kesinlikle katılmıyorum 2- Katılmıyorum 3-Kararsızım 4-Katılıyorum 5-Kesinlikle katılıyorum şeklinde beş seçenekli ölçeklerle ölçülmüştür.

\subsection{Verilerin Analizi}

Anket yoluyla toplanan veriler SPSS paket programının 22. versiyonu kullanılarak bilgisayara aktarılmış ve kişilikle örgütsel sessizlik arasındaki ilişkiler analiz edilmiştir. Araştırmaya katılanların demografik özellikleri frekans ve yüzde olarak hesaplanmıştır. Katılanların mesleki tecrübeleri ve cinsiyetleri ile örgütsel sessizlik 
davranışları arasında istatistiki bakımdan anlamlı bir farklılık olup olmadığı bağımsız gruplar $t$ testi ve ANOVA analizi ile test edilmiştir. Bağımsız değişkenler olan beş faktör kişilik özelliklerinin alt boyutları ile bağımlı değişken olan örgütsel sessizlik arasındaki ilişkiler ve etkiler korelasyon ve regresyon analizleri ile test edilmiştir.

\subsection{Araştırmanın Kısıtları}

Araştırma bulguları Çankırı ilinde bulunan ana okulu, ilkokul, ortaokul ve liselerde görev yapan toplam 401 öğretmenle sınırlıdır. Dolayısıyla elde edilen sonuçlar sadece belirlenen örneklem dahilinde yorumlanabilmiş olup, bir genelleme söz konusu değildir. Araştırma belirli bir zaman aralığında yapıldığı için kesitsel bir çalışmadır. Araştırmada elde edilen kişilik ve örgütsel sessizliğe ilişkin bulgular ölçeklerin ölçme kapasiteleri ile sinırlıdır.

\section{Bulgular}

Farklı kişilik özelliklerine sahip öğretmenlerin örgütsel sessizlik davranışlarının nasıl olduğu ve beş faktör kişilik özelliklerinin örgütsel sessizlikle ilişkileri ve etkilerine yönelik bulgular elde edilmiştir. Ayrıca cinsiyet ve mesleki tecrübenin örgütsel sessizlik üzerindeki etkisine yönelik sonuçlar da raporlanmıştır.

\subsection{Araştırmanın Tanımlayıcı Bulguları}

Araştırmaya katılan 401 kişiye ait cinsiyet, yaş, medeni durum, öğrenim durumu, çocuk sahibi olma durumu, kaç yıldır bu mesleği yaptığı ve şu anki kurumunda kaç yıldır çalıştığına ilişkin sorulara verilen cevapların frekansları ve yüzdeleri hesaplanmıştır.

Tablo 1. Demografik Özellikler

\begin{tabular}{|c|c|c|c|c|c|c|c|}
\hline \multicolumn{2}{|c|}{ Değişkenler } & Frekans & Yüzde (\%) & \multicolumn{2}{|l|}{ Değişkenler } & Frekans & Yüzde (\%) \\
\hline \multirow[b]{2}{*}{ Cinsiyeti } & Kadın & 205 & 51,1 & \multirow{2}{*}{$\begin{array}{c}\text { Çocuğu var } \\
\text { mı? }\end{array}$} & Evet & 306 & 76,3 \\
\hline & Erkek & 196 & 48,9 & & Hayır & 95 & 23,7 \\
\hline \multirow{5}{*}{$\begin{array}{l}\text { Yaş } \\
\text { Aralığ1 }\end{array}$} & 25 ve alt1 & 11 & 2,7 & \multirow{5}{*}{$\begin{array}{l}\text { Kaç yıldır } \\
\text { çalışıyor? }\end{array}$} & 1 yildan az & 13 & 3,2 \\
\hline & $26-35$ & 151 & 37,7 & & $1-10$ yil & 144 & 35,9 \\
\hline & $36-45$ & 115 & 28,7 & & $11-20$ yil & 110 & 27,5 \\
\hline & $46-55$ & 97 & 24,2 & & \multirow{2}{*}{$\begin{array}{l}20 \text { yıldan } \\
\text { fazla }\end{array}$} & \multirow[t]{2}{*}{134} & \multirow[t]{2}{*}{33,4} \\
\hline & 56 ve üstü & 27 & 6,7 & & & & \\
\hline \multirow{3}{*}{$\begin{array}{l}\text { Medeni } \\
\text { Durumu }\end{array}$} & Bekâr & 64 & 16,0 & \multirow{6}{*}{$\begin{array}{c}\text { Bu kurumda } \\
\text { kaç yıldır } \\
\text { çalışıyor? }\end{array}$} & 1 yıldan az & 76 & 19,0 \\
\hline & Evli & 328 & 81,8 & & $1-10$ yil & 248 & 61,8 \\
\hline & Diğer & 9 & 2,2 & & $11-20$ y1l & 39 & 9,7 \\
\hline \multirow{3}{*}{$\begin{array}{l}\text { Öğrenim } \\
\text { Durumu }\end{array}$} & Ön Lisans & 10 & 2,5 & & $\begin{array}{l}20 \text { yıldan } \\
\text { fazla }\end{array}$ & 38 & 9,5 \\
\hline & Lisans & 335 & 83,5 & & & & \\
\hline & Lisansüstü & 56 & 14.0 & & & & \\
\hline
\end{tabular}

Tablo 1'de görüldüğü gibi araştırmaya 401 kişi katılmış olup bunların 205'i (\%51,1) kadın ve 196'sı (\%48,9) erkektir. Yaş durumlarına göre 266 kişi (\%66,4), 26-45 yaş aralığındadır. Katılanların büyük çoğunluğunun 328 kişinin (\%81,8) medeni durumu evli olup, 306'sı (\%76,3) çocuk sahibidir. Katılımciların 335'inin (\%65,3) öğrenim durumu lisans olup, 248 kişi $(\% 61,8)$ şu anda bulunduğu kurumda 1-10 yıl arası çalışmaktadır.

\subsection{Hipotez Testleri}

H1: “Öğretmenlerin örgütsel sessizliği cinsiyetlerine göre anlamlı bir farklılık gösterir" hipotezi bağımsız örneklem $t$ testi ile ölçülmüştür. 
Tablo 2. Öğretmenlerin Cinsiyetleriyle Örgütsel Sessizlik İlişkisine Yönelik t Testi Sonuçları

\begin{tabular}{|c|c|c|c|c|c|c|}
\hline \multirow{2}{*}{ Cinsiyeti } & Sayı & Ortalama & Standart Sapma & s.d. & $\mathbf{t}$ & $\mathbf{P}$ \\
\cline { 1 - 5 } Kadin & 205 & 3,1042 &, 53936 & 399 & 3,902 &, 017 \\
\cline { 1 - 5 } Erkek & 196 & 2,8786 &, 61738 & & \\
\hline
\end{tabular}

Tablo 2'de görüldüğü gibi cinsiyetin örgütsel sessizlik davranışına etkisine yönelik H1 hipotezini test etmek amacıyla yapılan $t$ testinde 0,05 anlamlılık düzeyinde $\mathrm{P}<0,05$ olduğundan $\mathrm{H} 1$ hipotezi kabul edilmiştir. Öğretmenlerin sessiz kalma davranışları cinsiyete göre anlamlı bir farklılık göstermektedir. Kadınların ortalaması daha yüksek olduğundan kadın öğretmenlerin erkeklere göre daha çok örgütsel sessizlik davranışında bulundukları yani sessiz kaldıkları görülmektedir.

H2: “Öğretmenlerin örgütsel sessizliği meslekteki tecrübelerine göre anlamlı bir farklılık gösterir” hipotezi için mesleki tecrübeye göre dört bağımsız grup olduğundan ANOVA analizi yapılmıştır.

Tablo 3. Öğretmenlerin Mesleki Tecrübeleriyle Örgütsel Sessizlik İlişkisine Yönelik ANOVA Analizi

\begin{tabular}{|c|c|c|c|c|c|}
\hline Mesleki Tecrübe & Sayı & Ortalama & Standart Sapma & F & $\mathrm{p}$ \\
\hline 1 y1ldan az & 13 & 3,2510 & 47667 & \multirow{4}{*}{5,716} & \multirow{4}{*}{ 001 } \\
\hline $1-10$ y1l & 144 & 3,0899 & ,56005 & & \\
\hline $11-20$ y1l & 110 & 3,0321 & ,55444 & & \\
\hline 20 yıldan fazla & 134 & 2,8346 & 62492 - - & & \\
\hline
\end{tabular}

Tablo 3'deki ANOVA analizi sonuçlarına göre anlamlılık düzeyi $\mathrm{P}<0,05$ olduğundan $\mathrm{H} 2$ hipotezi kabul edilmiştir. Örgütsel sessizlik ortalaması öğretmenlerin mesleki tecrübelerine göre anlamlı farklılık göstermektedir. Mesleki tecrübesi bir yıldan az olanların örgütsel sessizlik ortalaması diğerlerinden daha düşüktür. Mesleğe daha yeni başlayan ve tecrübesiz olanların bilgi ve tecrübe eksikliğinden dolayı diğer gruplara göre daha çok sessizlik davranışı gösterdiği söylenebilir.

Tablo 4. Öğretmenlerin Mesleki Tecrübeleriyle Örgütsel Sessizlik İlişkisine Yönelik Scheffe Analizi

\begin{tabular}{|c|c|c|c|c|}
\hline Mesleki Tecrübe (I) & Mesleki Tecrübe (J) & Ort. Fark (I-J) & Std. Hata & Anlamlilik \\
\hline \multirow[t]{3}{*}{1 yıldan az } & $1-10$ yıl & , 16110 & ,16764 &, 820 \\
\hline & $11-20$ yil & ,21895 & , 16977 & 645 \\
\hline & 20 yildan fazla & ,41637 & , 16815 & 107 \\
\hline \multirow[t]{3}{*}{$1-10$ yil } & 1 yildan az &,- 16110 & , 16764 & 820 \\
\hline & $11-20$ yil & ,05785 & ,07330 & 891 \\
\hline & 20 yıldan fazla & , 25527* & , 06948 & 004 \\
\hline \multirow[t]{3}{*}{$11-20$ yıl } & 1 yıldan az &,- 21895 & , 16977 & 645 \\
\hline & $1-10$ y1l &,- 05785 &, 07330 & 891 \\
\hline & 20 yıldan fazla & , 19741 & , 07448 & ,073 \\
\hline \multirow[t]{3}{*}{20 yıldan fazla } & 1 yıldan az &,- 41637 & , 16815 & 107 \\
\hline & $1-10$ yil &,$- 25527^{*}$ & ,06948 & ,004 \\
\hline & $11-20$ yil & -19741 & , 07448 & ,073 \\
\hline
\end{tabular}

Tablo 4'e göre gruplar arası ilişkilere baktığımızda gruplar arasında örgütsel sessizlik davranışı açısından mesleki tecrübesi 20 yıldan fazla olanlarla 1-10 yıl arası olanlarda anlamlı farklılık görülmektedir. Mesleki tecrübeleri 20 yıldan fazla olanların örgütsel sessizlik ortalamaları daha düşük çıkmış, bir yıldan az olanların ortalamaları daha yüksek çıkmıştır. Buna göre mesleki tecrübe arttıkça öğretmenlerin daha az sessizlik davranışı gösterdiği, mesleki tecrübe azaldıkça örgütsel sessizlik davranışının arttı̆̆ı yani daha sessiz kaldıkları söylenebilir. 
H. Dağlar 12/3 (2020) 2487-2500

H3. “Öğretmenlerin beş faktör kişilik özellikleri ile örgütsel sessizlik davranışı arasında istatistiksel olarak anlamlı bir ilişki vardır" hipotezi test edilmiştir.

Tablo 5. Tanımlayıcı İstatistikler

\begin{tabular}{|l|c|c|c|}
\hline & Ortalama & Standart Sapma & Say1 \\
\hline Örgütsel Sessizlik & 2,9940 &, 58901 & 401 \\
\hline Dişa Dönüklük & 3,9177 &, 72420 & 401 \\
\hline Uyumluluk & 4,2456 &, 51491 & 401 \\
\hline Sorumluluk & 4,0611 &, 59844 & 401 \\
\hline Duygusal Dengelilik & 3,2594 &, 87038 & 401 \\
\hline Deneyime Açılılk & 4,0449 &, 64361 & 401 \\
\hline
\end{tabular}

Tablo 5' de ankette sorulan örgütsel sessizlik ve beş faktör kişilik özelliklerinden dişa dönüklük, uyumluluk, sorumluluk, duygusal dengelilik ve deneyime açıklıkla ilgili sorulara verilen cevaplarla ilgili tanımlayıcı istatistikler yer almaktadır.

Öğretmenlerin kişilik özellikleri ile örgütsel sessizlik tutumları arasındaki ilişki Pearson korelasyon katsayısı ile hesaplanmıştır.

Tablo 6. Analiz Sonuçları -(Korelasyon)

\begin{tabular}{|c|c|c|c|c|c|c|c|}
\hline & & $\begin{array}{l}\text { Örgütsel } \\
\text { Sessizlik }\end{array}$ & $\begin{array}{c}\text { Dişa } \\
\text { Dönüklük }\end{array}$ & Uyumlu. & Sorumlu. & $\begin{array}{l}\text { Duygusal } \\
\text { Dengelilik }\end{array}$ & $\begin{array}{l}\text { Deneyime } \\
\text { Açıklık }\end{array}$ \\
\hline \multirow{6}{*}{$\begin{array}{l}\text { Pearson } \\
\text { Correlation }\end{array}$} & $\begin{array}{l}\text { Örgütsel } \\
\text { Sessizlik }\end{array}$ & 1,000 &,- 238 &,- 012 &,- 084 &,- 235 &,- 157 \\
\hline & Dişa Dönük. &,- 238 & 1,000 & , 145 & , 180 & ,196 & ,342 \\
\hline & Uyumluluk &,- 012 & ,145 & 1,000 & ,328 & ,221 & ,244 \\
\hline & Sorumluluk &,- 084 & , 180 & ,328 & 1,000 & , 185 & ,265 \\
\hline & $\begin{array}{c}\text { Duygusal } \\
\text { Dengelilik }\end{array}$ &,- 235 & ,196 & ,221 & 185 & 1,000 & ,142 \\
\hline & $\begin{array}{l}\text { Deneyime } \\
\text { Açıklık }\end{array}$ &,- 157 & ,342 & ,244 & ,265 & , 142 & 1000 \\
\hline \multirow{6}{*}{$\begin{array}{c}\text { Sig } \\
\text { (1-tailed) }\end{array}$} & $\begin{array}{l}\text { Örgütsel } \\
\text { Sessizlik }\end{array}$ & . & , 000 & 402 & ,046 & , 000 & ,001 \\
\hline & Dişa Dönük. & ,000 & & ,002 & ,000 & , 000 & ,000 \\
\hline & Uyumluluk & ,402 & ,002 &. & ,000 & , 000 & ,000 \\
\hline & Sorumluluk & ,046 & ,000 & ,000 & . & ,000 & , 000 \\
\hline & $\begin{array}{c}\text { Duygusal } \\
\text { Dengelilik }\end{array}$ & ,000 & ,000 & ,000 & ,000 & . & ,002 \\
\hline & $\begin{array}{c}\text { Deneyime } \\
\text { Açıklık }\end{array}$ & ,001 & ,000 & ,000 & ,000 & ,002 & \\
\hline
\end{tabular}

Tablo 6' da bağımsız değişkenlerle bağımlı değişken arasındaki ikili korelasyonlar görülmektedir. Buna göre bağımlı değişken olan örgütsel sessizlikle, bağımsız değişkenler olan dışa dönüklük, uyumluluk, sorumluluk, duygusal denge ve deneyime açıklık arasında negatif olarak düşük derecede bir ilişki bulunmuştur. Bunlardan dışa dönüklük, duygusal dengelilik ve deneyime açıklık ile örgütsel sessizlik arasındaki ilişki (sig.<0,05) olduğundan anlamlı gözükmektedir.

Beş faktör kişilik özelliklerinden oluşan bağımsız değişkenlerin, örgütsel sessizlik bağımlı değişkeni üzerindeki etkisini belirlemeye yönelik regresyon analizi yapılmıştır. 
Tablo 7. Regresyon Modeli Özeti

\begin{tabular}{|c|c|c|c|c|}
\hline Model & $\mathrm{R}$ & $\mathrm{R}^{2}$ & Düzeltilmiş $\mathrm{R}^{2}$ & Std. Tahmin Hatası \\
\hline 1 &, $323 \mathrm{a}$ &, 104 &, 093 &, 56101 \\
\hline
\end{tabular}

a. Tahminler (Sabit): Dışa dönüklük, Uyumluluk, Sorumluluk, Duygusal denge ve Deneyime açıklık

Tablo 7'ye göre dışa dönüklük, uyumluluk, sorumluluk, duygusal denge ve deneyime açklık değişkenlerinin örgütsel sessizlik üzerindeki etkisini gösteren regresyon oranı 0,323'dür. Bu beş bağımsız değişken, bağımlı değişkendeki değişimlerin \%10,4'ünü açıklamaktadır.

Tablo 8. Çoklu Regresyon Modelinin Anlamlılık Sonuçları - (ANOVAa $)$

\begin{tabular}{|l|l|c|c|c|c|c|}
\hline \multicolumn{2}{|l|}{ Model } & $\begin{array}{c}\text { Kareler } \\
\text { Toplamı }\end{array}$ & Sd & $\begin{array}{c}\text { Kareler } \\
\text { Ortalamas1 }\end{array}$ & F & Sig. \\
\hline \multirow{2}{*}{1} & Regresyon & 14,454 & 5 & 2,891 & 9,185 &, $000^{\mathrm{b}}$ \\
\cline { 2 - 7 } & Atık (Residual) & 124,318 & 395 &, 315 & & \\
\cline { 2 - 7 } & Toplam & 138,772 & 400 & & & \\
\hline
\end{tabular}

a. Bağımlı Değişken: Örgütsel Sessizlik

b. Tahminler (Sabit): Dışa dönüklük, Uyumluluk, Sorumluluk, Duygusal denge ve Deneyime açıklık

Tablo 8'e göre F testinin anlamlılık değeri 0,05 den küçük (Sig. $=0,000<0,05)$ olduğundan regresyon modeli önemli olup tahminde kullanılabilir. Dışa dönüklük, uyumluluk, sorumluluk, duygusal denge ve deneyime açılık değişkenlerinin örgütsel sessizlik üzerindeki etkisi istatistiki açıdan anlamlıdır. Bundan dolayı “Öğretmenlerin beş faktör kişilik özellikleri ile örgütsel sessizlik davranışı arasında istatistiksel olarak anlamlı bir ilişki vardır" şeklinde olan H3 hipotezi kabul edilmiştir.

Tablo 9. Çoklu Regresyon Modeline Ait Katsayılara

\begin{tabular}{|c|c|c|c|c|c|c|}
\hline \multirow{2}{*}{\multicolumn{2}{|c|}{ Model }} & \multicolumn{2}{|c|}{$\begin{array}{c}\text { Standartlaştırılmamış } \\
\text { Katsayılar }\end{array}$} & \multirow{3}{*}{$\begin{array}{c}\text { Standart } \\
\text { Katsayılar } \\
\text { Beta }\end{array}$} & \multirow{3}{*}{$\begin{array}{c}t \\
13,623 \\
\end{array}$} & \multirow{3}{*}{$\begin{array}{l}\text { Sig. } \\
, 000\end{array}$} \\
\hline & & \multirow{2}{*}{$\begin{array}{c}\text { B } \\
3,985 \\
\end{array}$} & \multirow{2}{*}{$\begin{array}{c}\text { Std. Hata } \\
, 293\end{array}$} & & & \\
\hline 1 & (Sabit) & & & & & \\
\hline & Dışa Dönüklük & -146 & ,042 & -179 & $-3,476$ & ,001 \\
\hline & Uyumluluk & ,098 & 059 & ,085 & 1,647 & , 100 \\
\hline & Sorumluluk &,- 020 & 051 &,- 021 &,- 397 & ,692 \\
\hline & Duygusal Dengelilik &,- 138 & ,034 &,- 204 & $-4,091$ & ,000 \\
\hline & Deneyime Açıklık &,- 075 & ,048 &,- 082 & $-1,561$ & ,119 \\
\hline
\end{tabular}

Tablo 9'da regresyon analizi sonucunda beş faktör kişilik özellikleriyle ilgili bağımsız değişkenlerin bağımlı değişken olan örgütsel sessizlik üzerindeki etkisi görülmektedir. Standardize edilmiş Beta katsayısına göre, bağımsız değişkenlerin bağımlı değişken üzerinde etkisindeki önem sırası duygusal denge (Beta=-,204), dışa dönüklük (Beta=-,179), Uyumluluk (Beta=,085), deneyime açıklık (Beta=-,082) ve sorumluluk (Beta=-,021) şeklinde sıralanmaktadır.

Regresyon katsayılarının anlamlılığına ilişkin $t$ testinin sonuçlarına göre dışa dönüklük değişkeninin örgütsel sessizlik üzerindeki etkisi anlamlıdır (Sig.=,001<0,05). Yani dışa dönüklüğün örgütsel sessizlik üzerine etkisi vardır. Bu sonuca göre “Öğretmenlerin beş faktör kişilik özelliklerinden dışa dönüklük alt boyutunun örgütsel sessizlik üzerinde anlamlı bir etkisi vardır" şeklindeki H31 hipotezi kabul edilmiştir.

Uyumluluk değişkenine ilişkin $t$ testinin sonuçlarına göre anlamlılık değeri (Sig. $=, 100>0,05)$ olduğundan Beta 2 parametresi önemli değildir. Yani uyumluluğun örgütsel sessizlik üzerine etkisi yoktur. Bu sonuca göre "Öğretmenlerin beş faktör kişilik özelliklerinden uyumluluk alt boyutunun örgütsel sessizlik üzerinde anlamlı bir etkisi vardır" şeklinde ifade edilen $\mathrm{H}_{2} 2$ hipotezi reddedilmiştir.

Sorumluluk değişkenine ilişkin $t$ testinin sonuçlarına göre anlamlılık değeri (Sig. $=, 692>0,05)$ olduğundan Beta 3 parametresi önemli değildir. Yani sorumluluğun örgütsel sessizlik üzerine istatistiki olarak anlamlı bir etkisi yoktur. Bu sonuca göre “Öğretmenlerin beş faktör kişilik özelliklerinden sorumluluk alt boyutunun örgütsel 
sessizlik üzerinde anlamlı bir etkisi vardır" şeklindeki H3з hipotezi de reddedilmiştir.

Duygusal dengelilik değişkenine ilişkin $t$ testinin sonuçlarına göre anlamlılık değeri $($ Sig. $=, 000<0,05)$ olduğundan Beta 4 parametresi önemlidir. Yani duygusal dengelilik değişkeninin örgütsel sessizlik üzerine etkisi vardır. Bu sonuca göre "Öğretmenlerin beş faktör kişilik özelliklerinden duygusal dengelilik alt boyutunun örgütsel sessizlik üzerinde anlamlı bir etkisi vardır" şeklinde ifade edilen H34 hipotezi kabul edilmiştir.

Regresyon katsayılarının anlamlılı̆̆ına ilişkin $t$ testinin sonuçlarına göre deneyime açıklık değişkeninin anlamlılık değeri (Sig.=,119>0,05) olduğundan Beta 5 parametresi önemli değildir. Yani deneyime açılık değişkeninin örgütsel sessizlik üzerinde istatistiki olarak anlamlı bir etkisi yoktur. Bu sonuca göre “Öğretmenlerin beş faktör kişilik özelliklerinden deneyime açıklık alt boyutunun örgütsel sessizlik üzerinde anlamlı bir etkisi vardır" şeklinde ifade edilen $\mathrm{H}_{3}{ }_{5}$ hipotezi reddedilmiştir.

Bu sonuçlara göre uyumluluk, sorumluluk ve deneyime açılık bağımsız değişkenlerinin, örgütsel sessizlik bağımlı değişkeni üzerinde istatistiki olarak anlamlı bir etkilerinin olmadığ ve duygusal dengelilik bağımsız değişkenlerinin ise, örgütsel sessizlik bağımlı değişkeni üzerinde anlamlı bir etkisinin olduğu bulunmuştur. Beş faktör kişilik özelliklerinin alt boyutlarından dişa dönüklük ve duygusal dengelilik kişilik özelliklerine sahip olanların işyerinde daha az örgütsel sessizlik davranışı gösterdiği söylenebilir.

\section{Sonuç ve Tartışma}

Bu çalışmada beş faktör kişilik özelliklerinin örgütsel sessizlikle ilişkileri ve etkileşimleri araştırılmıştır. Ayrıca demografik özelliklerden cinsiyet ve mesleki tecrübeye göre öğretmenlerin örgütsel sessizlik davranışında anlamlı farklılık olup olmadığı da incelenmiştir.

Öğretmenlerin örgütsel sessizliğinin cinsiyetlerine göre anlamlı bir fark oluşturduğu tespit edilmiştir. Diğer bir ifade ile öğretmenlerin kadın veya erkek olmasına göre işyerindeki örgütsel sessizlik davranışı farklılaşmaktadır. İşyerinde sessiz kalmayı ölçen örgütsel sessizlik ölçeğinin kadın öğretmenlerin ortalamaları erkek öğretmenlere göre daha yüksek çıkmıştır. İşyerinde cinsiyete göre örgütsel sessizlik davranışında anlamlı farklılık bulunmuştur. Kadın öğretmenlerin erkek öğretmenlere göre okuldaki sorunlarla ve konularla ilgili bilinçli olarak konuşmamayı ve sessiz kalmayı tercih ettikleri görülmektedir. Yöneticilerin bu durumu dikkate alarak kadın öğretmenlerin fikirlerini ifade etmeleri konusunda daha hassas davranmaları ve onların görüşlerini dile getirmeleri hususunda teşvik edici olmaları gerekir.

Öğretmenlerin mesleki tecrübelerine göre örgütsel sessizlik davranışlarında anlamlı bir fark olduğu tespit edilmiştir. Öğretmenlerin mesleki tecrübelerine göre örgütsel sessizlik ortalaması istatistiki olarak anlamlı bir farklılık göstermektedir. Meslekteki tecrübesi bir yıldan az olanların örgütsel sessizlik ortalaması diğerlerinden daha düşüktür. Mesleğe daha yeni başlayan öğretmenlerin bilgi ve tecrübe eksikliğinden dolayı işyerinde daha çok sessiz kaldıkları söylenebilir. Mesleki tecrübeleri 20 yıldan fazla olanların örgütsel sessizlik ortalamaları daha düşük çıkmıştır. Mesleki tecrübe arttıkça öğretmenlerin daha az sessizlik davranışı gösterdiği, mesleki tecrübe azaldıkça örgütsel sessizlik davranışının arttığı yani mesleki tecrübe ile örgütsel sessizlik davranış ve tutumu arasında ters bir orantı olduğu tespit edilmiştir. Tecrübeli öğretmenlerin daha az sessiz kaldıkları, konuları ve sorunları daha çok dile getirdikleri söylenebilir. Mesleki tecrübeleri az olan öğretmenlerin örgütsel sessizlik davranışını azaltabilmek için yöneticilerin bu kişileri konuşmaları konusunda cesaretlendirmeleri, konuşmaya teşvik etmeleri ve bunun için uygun ortamı oluşturmaları gerekir.

Öğretmenlerin beş faktör kişilik özelliklerinin örgütsel sessizlikle ilişkileri ve etkileşimini incelemek üzere korelasyonlar hesaplanmıştır. Buna göre bağımlı değişken olan örgütsel sessizlikle, bağımsız değişkenler olan beş faktör kişilik özelliklerinin alt boyutları olan dışa dönüklük, uyumluluk, sorumluluk, duygusal denge ve deneyime açılık arasında negatif olarak düşük derecede bir ilişki bulunmuştur. Bunlardan dışa dönüklük, duygusal denge ve deneyime açıklık alt boyutları ile örgütsel sessizlik arasındaki ilişkinin anlamlı olduğu tespit edilmiştir.

Beş faktör kişilik özelliklerinin, bağımlı değişken olan örgütsel sessizlik üzerine etkileri araştırılmıştır. Yapılan regresyon analizi sonucunda uyumluluk, sorumluluk ve deneyime açıklık değişkenlerinin örgütsel sessizlik üzerine istatistiki olarak anlamlı bir etkisinin olmadığı tespit edilmiştir. Bunun yanında dışa dönüklük ve 
duygusal dengelilik değişkenlerinin örgütsel sessizlik üzerinde istatistiki olarak anlamlı bir etkiye sahip olduğu görülmüştür.

Kişilik özelliklerinin örgütsel sessizlik üzerindeki etkisine yönelik yapılan benzer bir araştırmada da, kişilik özelliklerinin örgütsel sessizliğe etkisi konusunda istatistiki olarak anlamlı sonuçlar bulunmuş ve dişa dönüklük özelliği yüksek olan kişilerin örgütte sessiz kalma eğilimlerinin daha düşük olduğu tespit edilmiştir (Tokmak, 2018:2229). Dolayısıyla bu araştırma bulguları, bu yönüyle literatürdeki ilgili araştırma sonuçlarıyla da benzerlik göstermektedir.

Örgütlerdeki verimliliği ve etkinliği artırmak, değişimi ve gelişimi sağlamak için çalışanların görüşlerinin alınması yoluyla yönetime katılmalarının sağlanması ve örgütsel sessizliği ortadan kaldıracak yol ve yöntemlerin uygulanması gerekir. Bu çalışmada kadın öğretmenlerin ve mesleki tecrübesi az olan öğretmenlerin diğerlerine göre işyerinde daha çok sessiz kaldıkları bulunmuştur. Bu gruptaki öğretmenlerin örgütte değişim, gelişim ve sorunların çözümüne katkıda bulunabilmeleri amacıyla işyerinde fikirlerini dile getirebilmeleri, sessiz kalmamaları yani konuşmaları için, yöneticilerin bunlara daha hassas davranması ve bu kişilerin cesaretlendirilmeleri gerekmektedir.

Beş faktör kişilik özellikleriyle örgütsel sessizlik davranışları arasında ilişki olduğundan, yöneticilerin öğretmenlerin görüşlerini almalarında ve yönetime katılmalarının sağlanmasında kişilik özelliklerine dikkat etmeleri ve çalışanların fikir, görüş ve düşüncelerini rahatça ifade edebilecekleri, açıkça konuşmalarını teşvik edecek ortamları sağlamaları, katılımcı ve demokratik yönetim için faydalı olacaktır.

Örgütsel sessizlik hem bireysel hem de örgütsel düzeyde olumsuzluklara neden olabileceğinden, örgütlerdeki sessizliği ve bunu ortaya çıkaran nedenleri anlamak ve bunları ortadan kaldırabilmek için işyerinde uygun ortamın sağlanması ve gerekli çabanın gösterilmesi gerekir.

Bu çalışmadan sonraki gelecek çalışmalarda çalışanların hangi konularda, kime karşı, hangi zamanlarda sessiz kaldıklarına dair derinlemesine araştırmalar yapılabilir. Ayrıca yönetim yapılarının ve yöneticilerin kişilik özelliklerinin örgütsel sessizliğe etkilerine yönelik araştırmaların yapılmasının da alana katkı sağlayacağı düşünülmektedir.

\section{KAYNAKÇA}

Alparslan, A.M. ve Kayalar, M. (2012). Örgütsel sessizlik: Sessizlik davranışları ve örgütsel ve bireysel etkileri, Mehmet Akif Ersoy Üniversitesi Sosyal Bilimler Enstitüsü Dergisi, 4 (6), 136-147.

Ardıç K. ve Gündoğmuş E. (2016). Bireylerin kişilik özelliklerinin işveren çekiciliği algısına etkisi, Journal at Behavior at Work, 1 (1), 1-14.

Atak, H. (2013). On-Maddeli kişilik ölçeğinin Türk Kültürü'ne uyarlanması, Nöropsikiyatri Arşivi Dergisi, 50, 312-319.

Ayduğ, D., Himmetoğlu, B. ve Turhan E. (2017). Öğretmenlerin örgütsel sessizliğe ilişkin görüşlerinin nitel bir araştırma ile incelenmesi, Abant İzzet Baysal Üniversitesi Ĕ̆itim Fakültesi Dergisi, 17 (3), 1120-1143.

Basım, H. N., Çetin F. ve Tabak A. (2009). Beş faktör kişilik özelliklerinin kişilerarası çatışma çözme yaklaşımlarıyla ilişkisi, Türk Psikoloji Dergisi, 24 (63), 20-34.

Costa, P. T., McCrae, R. R., and Dye, D. A. (1991). Facet scales for agreeableness and conscientiousness: A revision of the neo personality inventory, Personality and Individual Differences, 12 (9), 887-898.

Çakıcl, A. (2007). Örgütlerde sessizlik: Sessizliğin teorik temelleri ve dinamikleri, Çukurova Üniversitesi Sosyal Bilimler Enstitüsü Dergisi, 16 (1), 145-162.

Çakıcı, A. (2008). Örgütlerde sessiz kalınan konular sessizliğin nedenleri ve algılanan sonuçları üzerine bir araştırma, Çukurova Üniversitesi Sosyal Bilimler Enstitüsü Dergisi, 17 (1), 117-134.

Çakıcı, A. (2010). Örgütlerde İşgören Sessizliği: Neden Sessiz Kalmayı Tercih Ediyoruz?, Ankara, Detay Yayınevi.

Çavuşoğlu, S. ve Köse, S. (2016) Örgüt kültürünün örgütsel sessizlik davranışına etkisi, Dokuz Eylül Üniversitesi Sosyal Bilimler Enstitüsü Dergisi, 18 (1), 115-146. http://dx.doi.org/10.16953/deusbed.46003 
Durak, İ. (2014). Örgütsel sessizliğin demografik ve kurumsal faktörlerle ilişkisi: Öğretim elemanları üzerine bir araştırma, Atatürk Üniversitesi İktisadi ve İdari Bilimler Dergisi, 28 (2), 89-108.

Eren, E. (2008). Örgütsel Davranış ve Yönetim Psikolojisi (11.Baskı), İstanbul, Beta Yayınevi.

Erenler, E. (2010). Çalışanlarda sessizlik davranışının bazı kişisel ve örgütsel özelliklerle ilişkisi: Turizm sektöründe bir alan araştırması, Yayınlanmamış Doktora Tezi, Hacettepe Üniversitesi Sosyal Bilimler Enstitüsü, Ankara.

Gosling, S. D., Rentflow, P. J. and Swann W. B. (2003). A very brief measure of the big-five personality domains, Journal of Research in Personality, 37, 504-528.

Horzum, M. B., Ayas, T. ve Padır, M. A. (2017). Beş faktör kişilik ölçeğinin Türk kültürüne uyarlanması, Sakarya University Journal of Education, 7 (2), 398-408.

Karagöz, Y. (2017). SPSS ve AMOS Uygulamalı Nicel Nitel Karma Bilimsel Araştırma Yöntemleri ve Yayın Etiği. Ankara, Nobel Yayınevi.

Morrison, E. W. and Milliken, F. J. (2000). Organizational silence: A barrier to change and development in a pluralistic world, The Academy of Management Review, 25 (4), 706-725.

Ötken A. B. ve Cenkci T. (2013). Beş faktör kişilik modeli ve örgütsel muhalefet arasındaki ilişki üzerine bir araştırma, Öneri, 10 (39), 41-51.

Parlak Ö. ve Koçoğlu Sazkaya M. (2018). Beş faktör kişilik özelliklerinin iş yaşamında yalnızlık üzerine etkisi, Ordu Üniversitesi Sosyal Bilimler Araştırmaları Dergisi, 8 (1), 149-165.

Pinder, C. C. and Harlos, K. P. (2001). Employee silence: Quiescence and acquiescence as responses to perceived injustice, Research in Personnel and Human Resources Management, 20, 331-369.

Şimşek, E. ve Aktaş, H. (2014). Örgütsel sessizlik ile kişilik ve yaşam doyumu etkileşimi: Kamu sektöründe bir araştırma, Anadolu Üniversitesi Sosyal Bilimler Dergisi, 14 (2), 121-136.

Tatlılığlu, K. (2013). Beş faktör kişilik kuramı bağlamında kişilik kavramına genel bir bakış, Bingöl Üniversitesi Sosyal Bilimler Enstitüsü Dergisi, 3 (6), 127-146.

Tayfun A. ve Çatır, O. (2013). Örgütsel sessizlik ve çalışanların performansları arasındaki ilişki üzerine bir araştırma, İşletme Araştırmaları Dergisi, 5 (3), 114-134.

Tokmak, M. (2018). Kişilik özelliklerinin örgütsel sessizlik üzerindeki etkisine yönelik bir araştırma: banka çalışanları örneği, Hitit Üniversitesi Sosyal Bilimler Enstitüsü Dergisi, 11 (3), 2219-2233.

Tozkoparan, G. (2013). Beş faktör kişilik özelliklerinin çatışma yönetim tarzlarına etkisi: Yöneticiler üzerinde bir araştırma, Ekonomik ve Sosyal Araştırmalar Dergisi, 9 (2), 189-231.

Tutar, H. (2016). Sosyal Psikoloji, Ankara, Seçkin Yayıncılık.

Türk Dil Kurumu (2020). Güncel Türkçe Sözlük, http://www.tdk.gov.tr (Erişim tarihi:18 Nisan 2020).

Van Dyne, L., Ang S. and Botero I. C. (2003). Conceptualizing employee silence and employee voice as multidimensional constructs, Journal of Management Studies, 40 (6), 1359-1392. 